\title{
Vulnerable Life: Zombies, Global Biopolitics, and the Reproduction of Structural Violence
}

\author{
Steven Pokornowski \\ Division of Communications and Languages, Rio Hondo College, 3600 Workman Mill Rd., \\ Whittier, CA 90601, USA; spokornowski@riohondo.edu; Tel.: +1-568-908-3429 \\ Academic Editor: Myra Mendible \\ Received: 1 June 2016; Accepted: 17 August 2016; Published: 25 August 2016
}

\begin{abstract}
This essay offers an intervention in biopolitical theory-using the term "vulnerable life" to recalibrate discussions of how life is valued and violence is justified in the contemporary bioinsecurity regime. It reads the discursive structures that dehumanize and pathologize figures in U.S. zombie narratives against the discursive structures present in contemporary legal narratives and media reports on the killing of black Americans. Through this unsettling paralleling of structures, the essay suggests how the current ubiquity of zombies and the profusion of racial tension in the U.S. are related. In the process, the essay emphasizes the highly racialized nature of the zombie itself-which has never been the empty signifier it is often read as-and drives home just how dangerous the proliferation of postracial and posthuman discourses can be if they serve to elide historical limitations about the highly political determinations of just who is quite human.
\end{abstract}

Keywords: biopolitics; race; zombies; postracial; posthuman; \#BlackLivesMatter; violence

\section{Introduction: The Mattering of Lives, Life that Matters, and the Justification of Violence}

The zombie's recent cultural ubiquity parallels, and is in some measure symptomatic of, an increasingly visible racial tension in the U.S. That is not to say that such deaths as those of Trayvon Martin, Michael Brown, and Sandra Bland, to name just a few of those recently in need of memorialization, are a new phenomenon; nor is it to say that the structural disenfranchisement and systemic inequity that created the tense policing situations and rampant economic and political inequality in Ferguson, or Baltimore, or Chicago are new, either $[1,2]^{1}$. In fact, as recent evidence shows, these deaths are by no means new and they seem to mirror (both in their execution and their quantity) the history of lynchings in the United States [5]. This is but one facet of a larger structural inequality based largely on race that, due to a variety of social and legislative factors, has become linguistically, socially, and legislatively occluded.

As Michelle Alexander and others have demonstrated, in postracial and colorblind formations, old structural inequalities are maintained using different verbiage and justifications. Take, for example, Alexander's analysis of the disenfranchisement of black Americans through the criminal justice system, a means of restructuring and renaming caste-based systems of inequality, a reformulation of Jim Crow in a contemporary moment where overt racism has become unacceptable ([1], p. 2). Or one can take for example broad socio-economic disparities that persist, such as those identified by Teasley and Ikard in their criticism of postracial formulations [6]. Or take the examination of neoliberalism and colorblindness from Reagan to Obama provided in the third edition of Omi and Winant's Racial Formation in the United States, which historicizes the convergence of neoliberalism and colorblind

1 For more on this issue, see \#Ferguson syllabi such as those offered by Sociologists for Justice [3,4]. These syllabi listed—suggested to me by Amanda Phillips and Kim Knight-were integral in thinking through this paper. 
discourse, with the latter functioning as one of - ultimately the most successful-the racial reaction's various attempts to rearticulate and contain the black movement and allied social movements [7]. Omi and Winant also stress how "national chauvinism consigned blacks and [American] Indians inferiority and subhumanity, which gave white settlers license to enslave the former, steal the land of the latter, and kill both ([7], p. 79). This essay examines how that racialized dehumanization, and the license to violence granted by it, are still embedded in U.S. culture. The essay focuses primarily on contemporary concerns regarding violence toward black Americans, but it is important to note that this cannot be disentangled from the historical legalized and legislative violence levied against American Indians [8], who still suffer disproportionately as victims of crime [9], and have largely been erased from discussions of race through its binarization in the U.S. [10 $]^{2}$. If this essay addresses the obscuring of the function of race in justifications of violence, then it should be noted that American Indians-and the settler colonial structures that allowed for their disenfranchisement, dehumanization, and genocide-are doubly obscured. These histories indicate that inequality and violence meted out along racial lines are nothing new.

In some measure, the contemporary moment is a novel one; however, because even though the structures of violence are old, the language used to justify them has changed, and thanks to social media and its potential for grassroots activism, the visibility of racial inequality and violence is newly heightened. As this essay shows, the development of zombie narratives actually reflects the rise of colorblind and postracial discourse, too, as the figure's connection to a historically black experience tied directly and spiritually to racism, slavery, and empire has become eroded and occluded by a medicalized narrative of infection. In light of all this, this essay argues that contemporary post-apocalyptic zombie fictions seize upon the visibility of racialized violence, normalize it, efface its racial dimension through the sleight of hand provided by monstrosity, and glorify it as an effort to maintain or restore humanity, civilization, or some other grandiose analog for a white supremacist status quo. The lived experience of people of color and the academic work of scholars of critical race, gender, and sexuality studies already attests to this.

The zombie's ascendance from campy niche-monster to culturally ubiquitous signifier belies its historical connection to slavery, colonialism, empire, and the racist and sexist violence that accompanied and enforced the structures of production and reproduction of those institutions. Let us not forget that the zombie was culturally appropriated. The figure was exported to the U.S. cultural imaginary after the American occupation of Haiti gave an ethnographer and sensational travel journalist access to the island [11,12]. A number of scholars have noted the ease with which Giorgio Agamben's biopolitical concept of the homo sacer can be related to the figure of the zombie, and the ways in which zombie narratives can teach us about real world biopolitics, both obliquely [13-15] and directly [16-18]. At the same time, scholarship has continued to address the zombie's relationship to race and racial violence [19]. All too seldom, however, do these two lines of zombie criticism explicitly meet [20-22]. The parallel rise in the popularity of all things zombie and the increasing visibility of violence directed at bodies of color in the U.S. is neither innocent nor coincidental, and criticism must reckon with that [23].

Whether audiences recognize it or not, the contemporary zombie still echoes its bloody legacy: it is visible in the presence of the machete and the U.S. fighter jet in 28 Days Later, the zombie-clearing militia that uncannily echoes a lynch mob at the end of Night of the Living Dead, and the Walking Dead's introduction of the character Michonne with its clear slave trade echoes. The fact that the zombie is a figure that embodies and enacts racial violence that is justified through the coproduction of dehumanizing rhetorics of monstrous and dysgenic alterity, reveals how the structures at work in zombie fictions are uncannily paralleled in the discourse surrounding racial violence in contemporary

2 This is not Moreton-Robinson's main point-which has more to do with tropes of migration and slavery in establishing a possessive, white American national identity. 
media. In other words, the violence directed toward bodies of color made visible in contemporary media mirrors the violence historically levied against the figure of the zombie in popular culture. Following this, the contemporary preoccupation with zombies appears as a symptomatic reaction, from which cultural critics can glean valuable lessons about race, biopolitics, and the valuation of life and the limits of the human. That is, this provides a window into how physical, systemic, and environmental violence are justified, and perhaps it can lead to a first step in intervening.

Contemporary racial and political violence have already led to profound investigations into how lives are socially valued, and which lives are seen as worth protecting in contemporary media and culture-breathing new life into biopolitical theory and discourse [24-28]. These questions have been raised continuously throughout the last few years by a plethora of disparate events from the uneven coverage of the 2015 Ebola pandemic in U.S. media and the scandalous airlifting and radical treatment of infected American doctors, to the conflict over whose deaths count as innocent, civilian deaths in the 2015 conflict between Israel and Palestine, to similar conversations surrounding those killed in U.S. drone strikes [29-31]. In a domestic context, these questions violently emerge among concerns surrounding racial violence and police brutality, as well as systemic slow violence aimed at communities of color, as emphasized by the Flint water crisis and the contamination of communities surrounding the Exide battery recycling plant in Los Angeles [32-34]. In other words, contemporary events make abundantly clear that in the practice of governance and the reporting of political developments, not all lives are seen as equally worthy of being lived, and health and security services are not distributed equally.

Thus, we are faced with two interrelated questions. First, we must ask: whose lives matter in the eyes of the law and the media? (Is the life of an American doctor worth more than an African doctor's? Is the life of an Israeli civilian more valuable than a Palestinian civilian? Are the lives of affluent suburbanites worth more than those of the urban working poor?) Any analysis of the former question raises another: how, then, is life mattered, defined, and valued in the contemporary moment? As much as these are deep, existential questions about ontology, they are also pragmatic epistemic questions about the material effects of social structures in establishing values. These are also the issues at the heart of new media activist campaigns such as \#BlackLivesMatter and \#SayHerName. These activist movements work to make systemic violence visible by identifying, disrupting, and naming it. In their very monikers, these activisms call out specific structures of violence that demonstrate the systemic devaluation of black life, and the double devaluation of the lives of women of color. \#BlackLivesMatter and \#SayHerName are also at once invocations: we are called by their very names to recognize the worth of black life, to recognize the humanity of and violence toward women (especially women of color). This essay is one small attempt to answer that call.

This essay aims to demonstrate how the structures and representations of violence made increasingly visible by \#BlackLivesMatter and \#SayHerName darkly and intimately reflect the structures of violence in historical zombie narratives, dating back to the figure's exportation from Haiti in W.B. Seabrook's 1929 ethnography The Magic Island. On one hand, this demonstrates how the zombie naturalizes and proliferates what Scott Lauria Morgensen has identified as the settler colonial biopolitical structure of Western modernity [35]. On the other hand, it also exemplifies how this biopolitical structure operates through, and finds its justification in, the language and logic of biomedical discourse, which limits the recognition of humanity through the limit of biological idealism, as demonstrated through the work of Sylvia Wynter [36,37].

The titular formation and main theoretical conception of this paper, vulnerable life, draws on Agamben's conception of bare life, Butler's conception of precarious life, and Weheliye's recalibration of "bare life and biopolitics discourse" $[24,27,28]$. Through a juxtaposition of zombie narratives and contemporary racial violence, this essay demonstrates how the relegation of individuals-and more importantly, groups of people-to zones of indistinction and bare life at once makes those people vulnerable - they are prone to suffer violence - and also uses their vulnerability as a justification to do violence to them and maintain their vulnerable status. 
Giorgio Agamben's conceptualization of bare life draws on the classical Roman figure of homo sacer (or sacred man), whose indistinct status as one that may be killed but not sacrificed places the figure at the margins of the state; however, the status of homo sacer as residing at once inside and outside society, existing in a zone of indistinction that negates his/her politically and socially entangled way of life, relegates homo sacer to mere life (zoe in Agamben's formulation) ([27], pp. 8-11). This figure-at once inside and outside the political order, relegated through sovereign decision to a zone of indistinction - then becomes for Agamben the foundation of political order. As he explains in State of Exception, this is "the original structure in which law encompasses living beings by means of its own suspension," an idea that Agamben traces in that book through Weimar and Nazi Germany in order to analyze and critique post-9/11 U.S. political policies like the USA Patriot Act [38]. For Agamben, then, the state itself becomes founded on the exclusion of individuals from the obligations and protections of that state, with the camp serving as a structural and spatial enactment of this dynamic: it is a "permanent spatial arrangement" that "nevertheless remains outside the law" ([27], p. 169). Those that enter the camp, then, become, like homo sacer, relegated to a zone of indistinction where "subjective right and juridical protection" are suspended, and they are reduced to a state of bare life ([27], p. 171).

Written in the aftermath of 9/11, Butler's Precarious Life is a collection of five essays that explore the connection between vulnerability, loss, and the justification and deployment of violence ([24], p. XI). Rather than focusing on the exception, Butler offers what she acknowledges is an opening or a provocation to begin theorizing how shared interdependency can form the basis for a global political community ([24], pp. XII-XIII). Ultimately, these essays push Butler toward the theorization of "a non-violent ethics" founded "upon an understanding of how easily human life is annulled," deploying an adaptation of Levinasian ethics of the encounter in order to critique-and potentially subvert-social and political justifications of and tendencies toward violence ([24], pp. XVII-XIX). Butler demonstrates how contemporary suspensions of law-she cites specifically the extralegal and indefinite detainment of prisoners at Guantanamo Bay-demonstrate a sovereignty in crisis, one that relies on international coalition and the global stage, while constituting a fiction of its own independent sovereignty. Butler argues that the extension of these "lawless and illegitimate" structures of power threaten to instrumentalize interdependence, reinforce self-serving states, and foreclose the possibility of new rights and recognitions in the global community ([24], p. 100). Whereas Agamben's theorization of bare life and the exception examines how the juridical exception allowing violence is foundational to sovereignty (and reformulated but still foundational in democratic states), Butler works to probe why society moves toward (military) violence, how mourning in particular, and speech in the social forum more broadly, is entangled with the justification of political violence. Crucial to Butler's analysis is her conceptualization of the vulnerability of life as a basis for a non-violent, interdependent, humanist ethics.

Butler begins Precarious Life by talking about the relationship between violence and vulnerability in the contemporary era of security and terror. Butler states that " $[\mathrm{t}] \mathrm{o}$ the extent that we commit violence, we are acting on another, putting the other at risk, causing the other damage, threatening to expunge the other," and that, to some extent, "we all live with this particular vulnerability" ([24], p. 29). She goes on to note that this vulnerability is not distributed evenly, exacerbated as it is by social and political conditions [24]. According to Butler, how we attend to this vulnerability can shape our political and social actions-we can acknowledge vulnerability and seek nonviolent solutions to conflict, or we can deny it and attempt to master it through combat. Ultimately, though, "[w]e cannot, however, will away this vulnerability. We must attend to it, even abide by it" ([24], p. 29). Butler asks us not to attempt to overcome our own vulnerability, because, she argues, these attempts tend to manifest in a denial of vulnerability through the making-vulnerable of others, whose increased vulnerability then functions to Other them ([24], p. 100). Rather, accepting vulnerability means recognizing our own position in the world, which is vulnerable to others and, perhaps, benefitting from the making vulnerable of those that are othered. 
Although in common parlance vulnerable is often taken to mean that which "may be wounded" or is "susceptible of receiving wounds or physical injury" or, of positions or places, "that which is open to attack," these are actually the second and third definitions of the term according to the Oxford English Dictionary [39]. The oldest definition recorded for the term in the OED is "[h]aving power to wound, wounding" [39]. This double-bind-the vulnerable is at once that which wounds and that which is susceptible to being wounded-emphasizes Butler's point that we all live with vulnerability, but it also demonstrates something about the logic at play in contemporary discourses of (in)security. To put it plainly: those who are the most vulnerable are also perceived by security forces (whether local police, military occupiers, or mercenary contractors) as the most dangerous. It produces a circular logic where those that are othered are made more vulnerable, and those that are made more vulnerable are othered. This essay explores this process of othering and making vulnerable through an examination of both zombie narratives and Darren Wilson's testimony in defense of his shooting Michael Brown: self-defensive justifications of violence portray vulnerable life as beastly, monstrous, pathological, and dangerously inhuman. Thus, the limits of humanity (and perhaps innocence) are constantly being shifted by complex assemblages of political relations (race, racialization, sex, sexuality, ability) around the vulnerability of life.

While Agamben focuses on legal (and extralegal) suspensions of rights and justifications of violence and Butler focuses on the relation between social, legal, and ethical tendencies toward violence, in Habeas Viscus Alexander G. Weheliye takes a more fragmented approach to thinking through the "social (after)life" of bare life ([28], p. 2). Weheliye examines how "race, racialization, and racial identities" in particular function as "sets of political relations" that relegate nonwhite subjects outside of the category of the human ([28], p. 3). He argues that biopolitical discourse and the concept of bare life misconstrue how pivotal race is to the modern conception of the human and how racializing assemblages "discipline humanity into full-humans, not-quite-humans, and nonhumans" ([28], p. 4). Weheliye, then, demonstrates just how crucial racializing assemblages have historically been in making (in the West, nonwhite) lives vulnerable. This allows us to examine, in particular, the role of race in making certain lives more or less vulnerable, in Butler's sense. At the same time, this theoretical framework connects the legal, the political, and the social proliferation (and experience) of violence to alterity via race. Thus, racism, racialization, and race are one set of strategies by which power is consolidated, sovereignty is validated, and vulnerability is disavowed, through the othering and making vulnerable of other groups marked by race. (That is not to say, however, that sex, sexuality, gender, and ability are not also deployed in this way, history suggests otherwise.) In this way, then, the idea of vulnerable life presented here is not a distinct theoretical conceptualization, but a demonstration of how bare life (and the political exception more broadly), which operates through racializing assemblages, marks particular groups as vulnerable-both dangerous and in danger ${ }^{3}$. The zombie, as a figure already caught up in theorizations of bare life, enmeshed in existential and political zones of indistinction-between life and death, human and monster, the camp and the colony, etc.- -and entangled with a profound history of racism and exploitation, offers a unique window to see how life is made vulnerable and violence justified, and how culture reflects (and reflects upon) that. Certainly, other monstrous figures—such as the vampire—can shed light on this formulation, as well ${ }^{4}$. The zombie, however, is uniquely suited to this purpose because in its history, as in the history of biopolitical discourse, race performs a foundational and structural function that has become obscured over time [40].

3 This point is made in slightly different terms by Weheliye, he states on page 35: "If bare life embodies a potential dimsension of contemporary politics as such, we might ask, then, why certain subjects are structurally more susceptible to personifying its actualization[.]".

4 I would also suggest that these different kinds of monsters are structured by different othering assemblages. While the vampire is certainly still a racial and racialized figure, it is perhaps more directly structured by its sexual alterity. 
Zombie fictions, from their earliest incarnations, dramatize the dehumanization of racialized black subjects while portraying them as sources of an ontologically terrifying alterity; zombies always threaten to spread their beastly inhumanity. Furthermore, contemporary zombie fictions enact a wish fulfillment where the-typically heteronormative masculine white male-hero slaughters the racialized, dehumanized, infectious hordes that besiege him. In fact, the visual and narrative proximity of The Walking Dead to the genre of the Western suggests that these desires are structured by settler colonial ideologies echoing the annihilation of Native Americans in the U.S. West. Zombie fictions dramatize contemporary global bioinsecurity and the source of their terror comes not from an impending death at the hands of a monstrous enemy, but the threat of conversion into the very inhuman, animalistic, vulnerable non-life (the disenfranchised, racialized masses) that claws at the borders. The zombie, then, is not just a figure for bare life, but a figure that embodies the paradoxical ways in which vulnerability is amplified through racializing otherness. Furthermore, the existential threat at the heart of these narratives is a reminder of the universality of vulnerability. In other words, as Susan Sontag wrote fifty years ago of science fiction disaster films in general, these narratives "reflect worldwide anxieties, and they serve to allay them" [41]. The proliferation of these narratives today reflects the proliferation of an anxiety, coded in the language of bioinsecurity and terror, that the very patriarchal white supremacist forces of Capital that have historically (re)produced the racialized, gendered, sexualized, and hemispheric inequalities that engender vulnerable life, simultaneously coproduce their own vulnerability and, as a result, (re)produce the justification of self-defensive violence; because, that which is made susceptible to violence is also made capable of violence.

The next section of this essay begins by offering a cultural history of the zombie in the U.S. context, with particular attention to how the zombie's inhumanity has historically been tied explicitly to race, sex, gender, and ability, and how the figure's exportation to the U.S. culture industry is directly related to colonialism, empire, capitalist exploitation, and cultural appropriation. It then traces how race, sex, and gender are still encoded in the figure, and how the structures of violence represented in zombie fictions hinge on the figure's inhumanity and its threat as a source of infectious monstrosity. This contagious alterity is then also presented as justification for self-defensive violence. The following examination shows how the history of the zombie in U.S. cultural production reflects highly racialized and sexualized violence that has been naturalized and sterilized through the zombie's current reception as an empty signifier. Finally, the essay addresses how portrayals of nonfictional violence in contemporary media, and the legal narrations aimed at justifying self-defensive violence darkly echo the discursive and narrative structure of violence in zombie fictions. Ultimately, this essay argues that zombie fictions at once dramatize and dismiss the directly racialized and sexualized structures of violence that deny nonwhite bodies humanity, portraying people of color as mere flesh. In the process, the essay also illustrates how \#BlackLivesMatter, \#SayHerName, and \#IfIDieInPoliceCustody are instrumental in making these structures of violence visible in contemporary media.

This introduction would be incomplete if I did not also situate myself as a scholar [42]. I am a cis-gendered, heteronormative, able-bodied white man, and I am among those who are least vulnerable to the structures of violence that this paper will excavate, analyze, and critique. That position of privilege and the blindness it engenders are not lost on me. I admit my privilege as an acknowledgement of the ideological assemblages and invisible systems that influence my perspective in writing this paper. I further acknowledge this analysis can only be partial, incomplete, and biased, and it is intended as a provocation to further discussion; supplement, respond, and correct where necessary. Finally, I would be largely ignorant of the structures and assemblages that have shaped my privilege without the tireless work of dedicated scholars of queer, black, and intersectional feminism, and critical race and postcolonial studies who have challenged me to see my subject position from other perspectives and ground my theory in history and praxis. They deserve transparent citation and are recognized in the acknowledgements. 


\section{Fleshly (In)Humanity: Zombies and the (Re)Production of Vulnerable Life}

A cultural history of the zombie in the U.S. must trace its exportation from the Caribbean, and acknowledge the neocolonial (or, perhaps the naturalized settler colonial) power structures that made this exportation possible. The figure that made its way to America in the sensationalist journalism of W.B. Seabrook's The Magic Island and captured the popular imagination in the first feature length zombie film, the Halperin brothers' White Zombie, was a decidedly American reimagining. The Caribbean figure of the zombie that Seabrook and the Halperin brothers popularized lay at the hub of diasporic intersection, where slavery, imperialism, colonialism, and political revolution reordered a unique mix of cultures and beliefs. Seabrook's exposure to the figure, however, was made possible through the American occupation of Haiti which formally began in 1915 when the Marines were sent to Port-au-Prince. This occupation was strategic - the Caribbean was crucial to supply routes in World War I-but was also directly tied to U.S. corporate and financial interests in Haiti, with U.S. companies controlling both the only major bank in Haiti and the vast Haitian American Sugar Company (HASCO). The U.S. occupiers held a paternalistic view of their Haitian 'wards,' and while this is at times visible in Seabrook's accounts of the islanders and their spiritual beliefs, it structures other contemporaneous accounts, such as those of John $\mathrm{H}$. Craige $[43,44]^{5}$. It is no wonder that the figure of the zombie-the ultimate embodiment of liminal, exploited Caribbean life, and the representation of a fear that slavery and exploitation would continue even after death-was on the minds of Caribbeans occupied by a foreign power that owned their only bank, had a direct relationship in promoting an exploitative sugar business, and paternalistically limited their cultural expression $[45,46]$.

U.S. occupation made the exportation and appropriation of the zombie possible, but earlier colonial and imperial projects shaped the figure itself, which is but one part of a larger spiritual and religious system, Vodou. It is important to recognize this history and to understand that Vodou is a living religion and should be respected as such ${ }^{6}$. As Maya Deren explains in Divine Horsemen: Living Gods of Haiti and Leslie G. Desmangles analyzes in the journal Anthropos, this religion resulted from the importation of Africans to Haiti (and the Caribbean at large) as slave laborers brought a broad variety of West African cultural and spiritual beliefs in contact with Indigenous Caribbean and Christian beliefs [49,50]. This diasporic spiritual and cultural entanglement was set in motion by the oppression of slavery and forced conversion to Christianity. Though the histories of other Caribbean islands-such as Dominica and Jamaica-are distinct, and important to recognize in their singularity, their shared histories of imperialist exploitation and slavery brought forth systems of belief such as Obeah, Santeria, and even Hoodoo in the U.S., that bear some similarities to the Haitian Vodou ([49], pp. 58-59). Out of this historical and spiritual context the zombie emerged as a figure of life made beastly, of humanity turned into a beast of burden, of slavery that did not end in death. And it is out of these historical and spiritual contexts that the zombie was appropriated and, like the bodies of some of the slaves whose fears the figure was emblematic of, exported to the U.S. for the gain of white men. This is a role that, to a large extent, the figure of the zombie has yet to escape.

\subsection{Medical Racism, the Clinical Gaze, and the Fleshliness of Vulnerable Life in The Magic Island and Tell My Horse}

As Zieger so eloquently puts it, "[a]s a lay anthropologist, sadist, cannibal, paranormal researcher, dabbler in black magic, alcoholic, sensational journalist, and suicide, Seabrook [...] specialized in

5 Craige's access to Haiti is even more directly tied to the U.S. occupation, as he was a Captain in the Navy who had a supervisory role in the gendarmerie in Haiti during the U.S. occupation. While Seabrook fetishizes blackness and Haitian spirituality and folklore, while also dismissing it as primitivism, Craige's perspective is more overtly paternalistic and racist, viewing Haitians as primitive and underdeveloped.

6 Vodou is also often spelled "Vodun" and is likely more familiar to most readers in its Anglicization, "Voodoo." To learn more about Vodou as a living religion and about what its transcorporeality can teach us about the social construction of theories of the mind and the self, see the work of Roberto Strongman $[47,48]$. 
violation" ([51], p. 738). Zieger explains how Seabrook's travel writing relied on a racial self-fashioning through which he cultivated a "black identity" but did so "as an emissary of white modernity"; this perspective gives Seabrook an ambivalent tone: he is at once paternalistic and dismissive of Haitian spiritualism, and absolutely invested in experiencing it and writing about it authoritatively for white audiences ([51], p. 739) $)^{7}$. This tone manifests in his account of seeing a zombie in the fields, in which Seabrook invokes the specter of biological racism, white paternalism, and, eventually, an ontological horror problematically tempered through Seabrook's memory of scientific experimentation on dogs. This is, effectively, part of the first American zombie narrative.

During his first encounter with a zombie, Seabrook describes the zombie in animalistic terms-at once expressing and reinforcing the apparent dehumanization of the zombified man:

Obediently, like an animal, he slowly stood erect-and what I saw then, coupled with what I had heard previously, or despite it, came as a rather sickening shock. The eyes were the worst. It was not my imagination. They were in truth like the eyes of a dead man, not blind, but staring, unfocused, unseeing. The whole face, for that matter, was bad enough. It was vacant, as if there was nothing behind it. It seemed not only expressionless, but incapable of expression ([12], p. 101).

Seabrook's assertion that the man is "like an animal" evokes the history of eugenic, criminological, and social Darwinist pseudo-scientific theories that considered people on eugenic-dysgenic, human-animal, or savage-civilized continuums, dehumanizing and debasing people of color as less human than white "races" [52]. After this initial description, the zombie is so dehumanized for (and by) Seabrook that he begins using the gender-neutral object pronoun "it" to refer to the figure. The experience proves "a rather sickening shock," and Seabrook's disgust is concentrated on the zombified man's eyes, which are "the worst" and those "of a dead man," but these observations are certainly "not [Seabrook's] imagination." The deadness of the zombie's eyes mark a symbolic closure of the ethical and in this man's face Seabrook at first sees nothing human with which to sympathize. The perceived reality of this zombified man's devitalization and dehumanization marks him as an object of ontological horror for Seabrook: the dead made live again, the human made beast of burden. As the man's eyes become the focal point for Seabrook, he faces an ontological and epistemological crisis. Seabrook is stricken "for the flash of a second" by "a sickening, almost panicky lapse in which [he] thought, or rather felt, 'Great God, maybe this stuff is really true, and if it is true, it is rather awful, for it upsets everything'" ([12], p. 101). He clarifies that by "everything" he specifically means "the natural fixed laws and processes on which all modern human thought and actions are based" ([12], p. 101). It is telling that what strikes him as awful is not the fate of the zombified man, here, but the possibility that "modern" (white, Western) philosophy and science may be limited in its scope and power, and that, perhaps, Haitian culture and spirituality hold insights of which "modern" science is ignorant. The vulnerable life of the figure is also a threatening one, as it shakes the foundations of Seabrook's own sense of security as an American (read: "modern," Western) subject.

Tellingly, Seabrook overcomes his shock at the zombie by reframing the spectacle through a clinical gaze. The "dead eyes" of the zombie are paralleled in his imagination with the eyes of a lobotomized dog he has seen in a lab experiment. The dog's "entire front brain had been removed in an experimental operation weeks before; it moved about, it was alive, but its eyes were like the eyes" of the zombified man now facing him ([12], p. 101). This memory, which allows Seabrook to equate the zombified man directly with a lobotomized dog, allows him to recover and compels him to reach out and touch the zombified man's hand. He is relieved to find it is "calloused, solid, human," leading him to calmly state that "naturally the zombies were nothing but poor, ordinary demented human beings, idiots, forced to toil in the fields" ([12], pp. 101-2). He appears to pity the man, but does not

7 Zieger provides a brief catalog of highly compelling quotes from Seabrook's writing to illustrate this point, her article is worth reading for its complex portrait of Seabrook's racial politics alone. 
express great concern at his condition. In this way, Seabrook's supposed firsthand account of a zombie demonstrates how, from its first representations in U.S. literature, the zombie embodied a complex entanglement of blackness, disability, animality, and biomedicalized dehumanization. After Seabrook grounds his experience as the witnessing of a medical abnormality, animalizing the figure through his direct parallel to the lobotomized dog, he returns to the zombified man a diminished humanity, and one only confirmed through touch. He allows that zombies may be human, but if so, they are "poor" and "demented" "idiots," echoing once again eugenic movements to castrate, or otherwise productively contain the disabled that were unequally deployed against the poor and populations of color.

Furthermore, the zombie's embodiment of this variegated dehumanization and animalization of blackness speaks to its role as what Alexander G. Weheliye, following Hortense Spillers, calls "flesh" ([28], p. 2). For Weheliye, "[t]he flesh, rather than displacing bare life or civil death, excavates the social (after)life of these categories: it represents the racializing assemblages of subjection that can never annihilate the lines of flight, freedom dreams, practices of liberation, and possibilities of other worlds" ([28], p. 2). The inhuman fleshliness of the zombie in Seabrook's firsthand account makes visible some of the racializing assemblages at play in U.S.-occupied Haiti in the wake of eugenics and the medical racism of the 1920s. This underscores the importance of understanding the zombie not as a post-racial, post-human figure, but an always racialized and dehumanized/pathologized figure, a life that is absolutely vulnerable and perceived as absolutely threatening, and it is only through a clinical, scientific approach to understanding the figure (which is, of course a spiritual one) that its threat is dispelled.

The zombie's role as vulnerable life-in both of its critical senses-as a figure of eerily inhuman fleshliness - is complicated when Seabrook relays the tale of "Toussel's Pale Bride." This story, which Seabrook explains was told to him by his Haitian friends, is about a woman whose husband brings her face to face with a group of zombies on the anniversary of their wedding night. As the story goes, ultimately, her husband brings her to dinner with four silent guests, asking her to forgive their rudeness and making the strange pronouncement that:

It has been a long time...since...they have...tasted wine...sat like this at table...with...with so fair a hostess...But, ah, presently...they will drink with you, yes...lift...their arms as I lift mine...clink glasses with you...more...they will arise and...dance with you...more...they will... [12], pp. 112-13).

At this moment, the wife, who remains Toussel's nameless bride in the narrative, lifts a candle to the face of a guest and sees that he is in fact a zombie, and she runs screaming from the scene. She is found the next dawn, "lying unconscious," her clothes "ripped and torn" ([12], p. 113). Due to her pale skin, she is at first mistaken for "a French lady," then for a "fancy prostitute" before she tells them her maiden name and asks to be taken to her family's home, where doctors and family members "gather from the girl's hysterical utterances a partial comprehension of what had happened" ([12], p. 114).

While Seabrook's firsthand account raises_and dismisses — the specter of race and class politics, reframing the question of slavery within a medical register, this second story seems to approach and obscure a commentary about sexual slavery. The end of the lengthy passage quoted above is exemplary of this, as Toussel describes a progressively increasing physicality and proximity to the zombies' relation to his wife-first they will drink with her, then clink glasses with her, then dance with her, and finally they will do "...more..." And, indeed, it is precisely when Toussel explains that they will do "...more..." that his nameless bride is struck with fear and flees the dinner and precipitates a narrative ellipsis-we leap from her flight at night to her rescue in the morning. This gap in the narrative gestures towards a sexual violence-an idea that is reinforced by the state of the bride's clothing, her hysteria, and her discoverer's thought that she might be a prostitute. Yet, this story itself is one made up of omissions; the bride is never named, and seventeen sets of ellipses punctuate Toussel's brief monolog. It is a story that suggests rather than states. It is a story that cannot be told. 
These stories show how the zombie began its cultural life in the U.S. as a complex embodiment of racial, colonial, and sexual fears. It is always already a gendered tale of violence, a figure of biologized difference, and the object of a clinically indifferent gaze. The zombie in the cane fields that Seabrook himself encounters is portrayed as medically inferior (an "idiot"), and as less vital and less human than normal. In fact, the only way that Seabrook can recognize his humanity is first to see him as a beast and then to touch him. This is a complicated and paradoxical double move, on the one hand, clinically approaching the zombie's vacant eyes allows Seabrook to see the figure as pathologically subnormal, a sort of brute or beastly life, but it is only when Seabrook overcomes the primacy of visual difference (doubly represented in the "vacant eyes") and touches the zombified man that he can recognize his humanity. Seabrook implies that one's eyes cannot be trusted. And yet, in the next story that he tells, proximity and touch are implicitly threatening. Here, we can see the zombified man as an embodiment of the dual nature of vulnerable life: on the one hand, he inspires a paternalistic response from Seabrook; on the other hand, the same vacant, silence of Toussel's zombies is refigured as menacing a sexual violence.

Writing against Seabrook nearly a decade later, Zora Neale Hurston's portrayal of the zombie in Haiti bears striking similarities [53]. The medical frame through which Seabrook rationalizes the zombie's existence is already in place during Hurston's personal encounter with a zombie. She describes how the "Director-General of the Service d'Hygiene" gives her permission to visit "a Zombie [that] had been found on the road and was now at the hospital" ([53], p. 195). Hurston calls her visit an "investigation" and she maintains a fairly objective, descriptive tone as she recounts watching the zombified woman move about the hospital yard. When the doctor clears the zombified woman's hands from her face so that Hurston can photograph her, Hurston's tone changes, and her language echoes Seabrook's as she describes " $t]$ hat blank face with the dead eyes," and explains that "[t]here was nothing you could say to her or get from her except by looking at her, and the sight of this wreckage was too much to endure for long" ([53], p. 195). In addition to reinforcing-if not elevating-the role of the clinical found in Seabrook's account, Hurston also focuses on both the eyes of the zombified woman and the visual. Unlike Seabrook, she does not reach out to touch the zombie, nor does she face an ontological or epistemological crisis. Instead, the clinical gaze is maintained, amplified by the use of photography, and reinforced through Hurston's assertion that the only thing you could "get from her" was obtained "by looking at her." For Hurston, the experience remains a scientific one; it is always an "investigation."

Hurston relays the history of the figure she meets, one Felicia Felix Mentor, and the tale has some striking similarities to the end of the story Seabrook relays as the tale of "Toussel's Pale Bride." Hurston explains that "[i]n 1907 [Mentor] took suddenly ill and died and was buried. There were the records to show. [...] Then one day in October 1936 someone saw a naked woman on the road and reported it to the Garde d'Haiti ([53], p. 196). Despite the "wretched condition" she was in, the woman's brother and husband identified her as Mentor and she was sent to hospital. Since then, she has spoken little, as zombies are "unable to tell anything" ([53], p. 205). Mentor's appearance-nude on the roadside-echoes the fate of Toussel's wife in the story relayed by Seabrook: she is discovered disheveled and nearly mute on the roadside. Only, in this case, Mentor herself is a supposed zombie, despite bearing roughly the same symptoms as Toussel's traumatized bride (whose language also largely failed her). In both tales, zombies are directly associated with what seems to be a sexual violence, directed at the bodies of women, which is doubly unspeakable - the victims cannot find the language to tell their tale and both narratives elide how the women came to be battered, dirty, and naked on the roadside.

These ethnographic accounts reveal three major facets of the zombie that have been adopted by zombie fiction with devastating political effects. In both firsthand accounts, the zombie can only be made legible through a clinical lens, one that Seabrook ties directly to pathological difference and animality. Following this, the presumed etiology of the zombie in both cases is a biomedical one-as Hurston seeks the zombifying drug and Seabrook refers to Haitian law forbidding drugging someone 
into a death-like lethargy. Finally, both accounts connect the figure to an exploitative violence done to black bodies and associated with the threat of sexual violence.

\subsection{Zombie Cinema and the Normalization and Justification of Violence}

The first feature length zombie film, White Zombie, borrows liberally from and was directly inspired by Seabrook's The Magic Island. The film takes elements directly from Seabrook's account of local customs and lifts facets from the zombie tales he relays: burial at the crossroads (presumably to avoid zombification); a reimagining of the tale of zombie slave labor at a HASCO-like sugar factory; and zombies walking single-file at night. The most important element the film takes from the book, however, is its imaginative use of the brief "Article 249" of the Code Pénal, which Seabrook relates to the reader at the very end of "...Dead Men Working in the Cane Fields." The article, as Seabrook transcribes and translates it, is as follows:

Article 249. Also shall be qualified as attempted murder the employment which may be made against any person of substances which, without causing actual death, produce a lethargic coma more or less prolonged. If, after the administering of such substances, the person has been buried, the act shall be considered murder no matter what result follows ([12], p. 103).

In White Zombie, Dr. Bruner-a priest, doctor, and Van Helsing-like aide to the protagonist—cites the article by number and reads a paraphrase of Seabrook's translation to the protagonist, Neil. In both The Magic Island and White Zombie, the article serves to validate the plausibility of a zombie threat. White Zombie also draws some of its major conflict from the article, seizing on the idea of a zombifying drug ${ }^{8}$. The villain of the film-Bela Lugosi as "Murder Legendre"—uses the mysterious "substance" and a combination of stereotypes of voodoo and mesmerism to zombify his victims. This use of both the legislative and the biomedical in framing the figure of the zombie lends it a rational credence, while further medicalizing the figure.

The zombifying substance, in fact, becomes a major feature of White Zombie. Early in the film, the substance is used in conjunction with stereotypes of voodoo and elements of mesmerism, Legendre emphasizing its potency by explaining that all it takes to successfully drug someone is "a single drop in a glass of wine, or maybe a flower" [11]. He steers the misguided Beaumont into drugging the film's main victim, and presumably the titular white zombie, Madeline, with a poisoned flower. Madeline's zombification features elements of voodoo stereotypes, such as the burning of a "voodoo doll" consisting of a wax effigy and a personal possession. At the same time, her zombification is also characterized through filmic references to mesmerism, most notably the superimposed apparition of Legendre's staring eyes (See Figure 1).

Legendre's control of zombies appears to function through his eyes and the use of a hand gesture, one that appears arbitrarily imagined for the film. Thus, in its first popular representation, the zombie was already exploited and modified as a figure, divorced from its cultural context and made and controlled with practices entirely divorced from voodoo. And yet, the focus on the gaze and the face persist. In this process, the zombie becomes westernized, and further biologized and medicalized-zombification is imagined not as a spiritual process wherein a dead body is reanimated without a soul; rather, it becomes a drug-induced state of diminished consciousness and will, predicated on the intersection of western stereotypes of voodoo, mesmerism, and behaviorism.

8 And, indeed, many others have since searched for such a drug, including Hurston, whose own ethnography takes a mystery-novelesque detour into secret societies and cannibal cults in search of the drug. More famously, Wade Davis conduncted an enthnobiological study in Haiti and claimed to identify "tetrodotoxin" as the culprit-Though he also explains that his search for a biological phenomenon led him to see this zombification as both a sociocultural practice and a medical one, acknowledging the role of community in the production of zombies. For more on this, see [54,55]. 


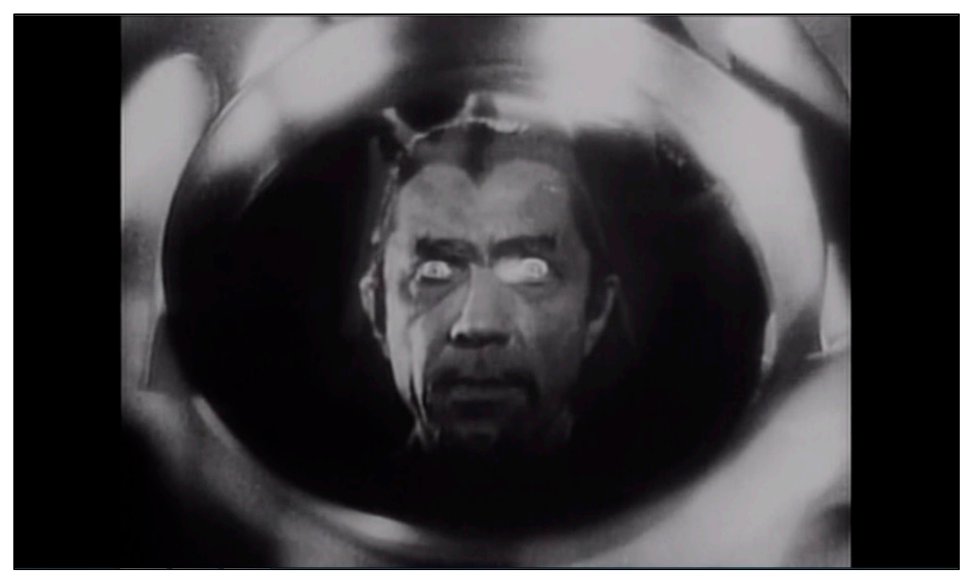

Figure 1. Murder Legendre's gaze. The focus on Lugosi's eyes, combined with the swirling, circular border of the frame emphasize the reference to mesmerism.

The forceful biologizing and medicalizing of the zombie already effected by Seabrook and reinforced in White Zombie reaches its apex near the end of the film. Beaumont sees the folly of his ways and desires to save Madeline, only to find himself drugged and zombified by the nefarious Legendre. Legendre gives Beaumont the aforementioned "single drop in a glass of wine" and poisons him. However, in this instance, Legendre foregoes the mystical and mysterious trappings at play throughout the rest of the film. He uses neither his staring eyes, nor his cryptic hand gesture, nor any other visible 'voodoo' trickery; he simply drugs Beaumont and studies him, even going so far as to present it as a medical experiment. Addressing an ill and mute Beaumont, Legendre muses: "Can you still hear me? It is unfortunate you are no longer able to speak, I should be interested to hear you describe your symptoms. You see, you are the first man to know what is happening" ([11], emphasis mine). By the end of the film, even cursory references to Haiti, voodoo, and the spiritual are foregone in favor of a purely biomedical lens-duplicating the logic of Seabrook's own experience with the zombie. This is also emphasized by the shift in setting from plantation mansions, tiki-like bars, and sugar mills to a gothic castle-the film symptomatically represents the westernization and cultural appropriation of the figure through its awkward changes in setting.

In this way, White Zombie participates in a sort of representative exploitation, taking the figure of the zombie from Haiti, decontextualizing it, despiritualizing it, and repackaging it as Western movie monster and biomedical aberration. In this dual exportation of the zombie and erasure of its local history, the troubling political history out of which the figure of the zombie is born is also obscured, yet traces of it are symptomatically reproduced. That is, the deracialized, often seen as postracial, nature of the modern zombie was quite violently and visibly formed through the first popular zombie film's own erasure of political and racial history. The film operates on two major fears: (1) that rational, modern white individuals may be exploited and controlled by people of color-that the island subjects can turn the American visitors into white zombies; and (2) that consequently this mind control will lead to sexual slavery and miscegenation. This function is obscured by the casting of Lugosi as the villain: he and his zombie entourage merely appear ambiguously ethnic (a fact emphasized by their oddly orientalized garb); however, despite his deceptively white appearance, Lugosi is directly associated with "the natives" in the film. And Neil and Dr. Bruner comment explicitly on the dangerous nature of said natives. After Madeline's body disappears from its mausoleum, Bruner claims that she may not be dead, but instead captured by natives. To which Neil dramatically and vitriolically responds: "Well, surely you don't think she's alive, in the hands of natives? Oh no, better dead than that!" [11]. The idea that it is better for Madeline to be dead than in the hands of natives underscores the racial and sexual fears of the film, and again—as in Seabrook and Hurston—the threat of sexual violence is 
only implied through lacunae. There, lying underneath the postracial surface is the violent history of racism, colonialism, and empire.

The film, then, forcefully remolds the figure of the zombie into a westernized biomedical monster, redefining it as a denationalized foreign threat, a dangerous pathological devaluing of life to its barest state, and one that threatens the sexual and racial purity of the West-especially the U.S. The film reinforces the biologizing and pathologizing of the figure of the zombie, and makes the figure's geographical and racial othering more overtly threatening. Furthermore, with the zombification of the innocent white woman, Madeline, the zombie becomes refigured as a racialized and sexualized foreign other that threatens Western, white patriarchal power. At the film's end, violence toward zombies-and their creator-is implicitly justified, in direct contrast with Seabrook's conclusions. As Legendre's zombies close in around Neil, he fires a revolver and we see the bullet wound appear without bleeding on a zombie: violence has no apparent effect, they feel no pain, they can be killed with impunity. Immediately after this, as Neil dives out of the way and the zombies walk off a cliff to their doom, the scopic gaze at the film's end parallels the destruction of the zombie in the sugar mill earlier in the film, as the camera shows us their fall, but not their destruction. When a semi-zombified Beaumont throws Legendre from the cliff, though, the camera follows his body as it falls hundreds of feet into rocky rapids. The implication here is twofold: (1) the foreign threat represented by Legendre is so vile that the audience is permitted to view and be assured of his destruction; and (2) the deaths of the zombies themselves, as undead inhumans, are of no note. In this way, zombie cinema immediately appropriated the figure of the zombie, further pathologized and dehumanized it, and then sanctioned and normalized violence done to the figure as a threat to White patriarchal supremacy. This formative shift actually still structures contemporary zombie fictions.

Romero's 1968 horror masterpiece, Night of the Living Dead, is routinely cited as a turning point in the representational history of the zombie [56]. It is often seen as the moment that divorced the zombie from its historical ties to Haiti, Vodou, and the history of oppression, and modernized the figure into the cannibalistic ambulatory corpse so familiar to pop-culture consumers today. Matt Mogk opens his pop-culture encyclopedia on zombies, Everything You Ever Wanted to Know About Zombies, with a vignette about that film's foundational status, ultimately concluding simply that, through Night of the Living Dead, "The modern zombie was born" ([57], p. 4). Academic scholarship supports both Mogk's assertion and his verbiage, offering only minor complications to this claim, such as analyzing Romero's hybridization of the zombie with other figures like the ghoul [58], noting the novelty of associating the undead with contagion in Night of the Living Dead [59], and detailing Romero's debt to (or plagiarization of) Richard Matheson's novel, I Am Legend, and its first film adaptation, The Last Man on Earth [60]. If there is any single consensus among critics, scholars, and fans of zombie fiction, it is that Night of the Living Dead was crucial in advancing the genre.

The author has argued elsewhere about the function of Night of the Living Dead on the imagination of global health and disaster and the sanction of violence [61], but the film makes hyperbolic the pathologizing and medicalizing of the zombie, more explicitly sanctions its destruction as an act of self-defense, and quite brilliantly demonstrates how the portrayal of the zombie as a posthuman, postracial other functions to elide the figure's structural collapsing of blackness and inhumanity. Eschewing for the sake of time a broader discussion of the dramatization of community versus security in the film, this essay will look at the way Night of the Living Dead considers white supremacist violence and attempts to maintain the status quo through necropolitical violence.

At the heart of the film is a power struggle between the two survivors-the African American protagonist, Ben, and his uptight white adversary, Harry-which figures as a clear portrayal of racial tension in the immediate aftermath of the assassination of Martin Luther King, Jr. This conflict takes on a structural characterization between the farmhouse, claimed by Ben, as a location of cooperation, community, and social life, and the cellar, claimed by Harry, as a space for the protection of life itself [62]. By the film's end, Ben, the sole survivor of the farmhouse, is shot dead by a zombie-clearing militia there, ostensibly, to eliminate zombies and rescue survivors. 
The scene is even more unsettling than it sounds, as it echoes both the Civil Rights movement and U.S. slavery. The police figures holding German Shepherds, tugging violently at their leashes, harks at once to famous media portrayals of Civil Rights protests, where the German Shepherd became a focal point (See Figure 2).

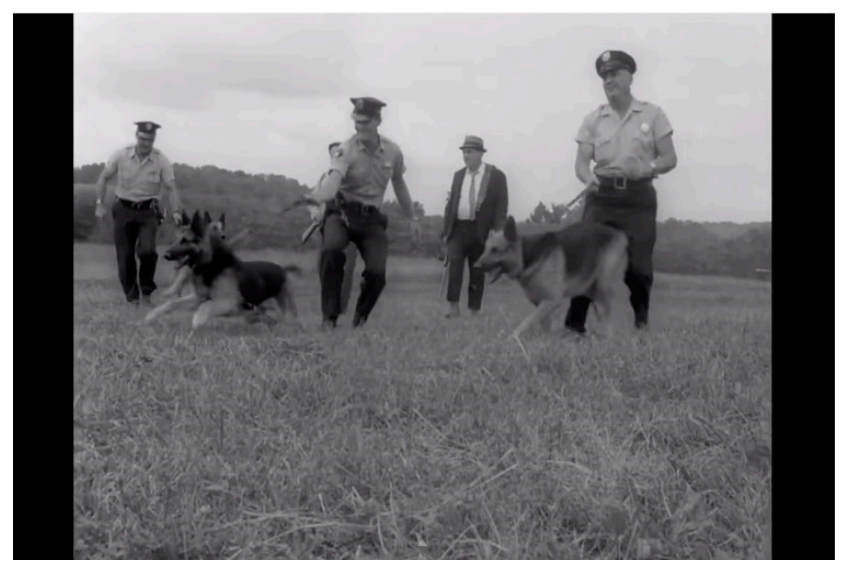

Figure 2. The zombie-clearing militia is led by the Sheriff-visible in the rear-and deputies. The German Shepherds add an unsettling familiarity to the imagery, invoking at once the threat of violence embodied in the presence of German Shepherds at Civil Rights demonstrations in the 1960s, as well as the historical use of dogs to track runaway slaves.

Furthermore, the violent, armed militia/search party utilizing the dogs echoes the hunting of runaway slaves in particular, and American slavery more generally, and heightens the sense that Ben appears indistinguishable from the zombies to the militia. His life is, indeed, vulnerable: he is threatened with death from both the zombies and the militia, and the militia sees him as another undead threat to them. There is something deeply unsettling in the implied parallel here: the live black man is seen as indistinguishable from the undead, pathological zombie. This juxtaposition is then reinforced in the final visual sequence of the film, as Ben's body is unceremoniously moved-using meathooks, emphasizing its non-sacred status as mere flesh - and laid to rest side by side with the very first shambling corpse of the film atop a crude, mass funeral pyre. For a brief moment, the camera rests on their unseeing faces, challenging the viewer to see a meaningful difference. It is a powerful visual motif, as out of context it emphasizes racism's constructedness, but considered in the film as a whole, it also drives home the effects of racism: the pathologization, dehumanization, and justification of violence toward racial others through the function of monstrosity and medical difference. The framed shot of just the two men's faces also gestures to the Levinasian ethics of the encounter, with which Butler engages in Precarious Life (See Figure 3).

In the end, the groups tasked with maintaining and defending life in the film are responsible for its destruction. Medical scientists, news media, and the militia all engage in the proliferation of necropolitics: the only way to maintain and defend normative, healthy life, all three affirm, is to kill the infected [25]. It becomes clear, as the survivors watch a rushed interview of scientists and military figures, that there is no definitive scientific understanding of the situation in the film. In the scene, a medical expert, a scientist, and a military official argue over whether radiation from a crashing satellite is conclusively responsible (See Figure 4).

All attempts in the film to scientifically explain the difference between the living, the dead, and the undead prove futile. (This is, in an odd way, parallel to the history of race in biological and medical science.) The only advice that scientists can offer is to kill the undead creatures by blows to the head-which the news media relays through emergency broadcasts, and the armed forces visibly enact. Thus, the best medical defense offered in the film is physical violence, advocating a prophylactic genocide of the reanimated dead, one that is refigured as a metaphor of racial violence 
in the film's final, traumatic sequences. Ultimately, Night of the Living Dead restructures the major tropes present in U.S. zombie narratives: it still features the pathologization and dehumanization of a racial other and it still represents the threat of racial contagion. Moreover, it more directly associates these elements with racial tension, and the conflict between Ben and Harry over the body of the semi-catatonic, hysterical Barbra manifests overtly the fears of miscegenation implicit in earlier zombie narratives. The previously unmatched primacy of contagion and self-defensive violence in the film has structured zombie narratives in its wake; however, the politically meaningful foregrounding of race (and implicitly racism) in the film is absent in the majority of its descendants.

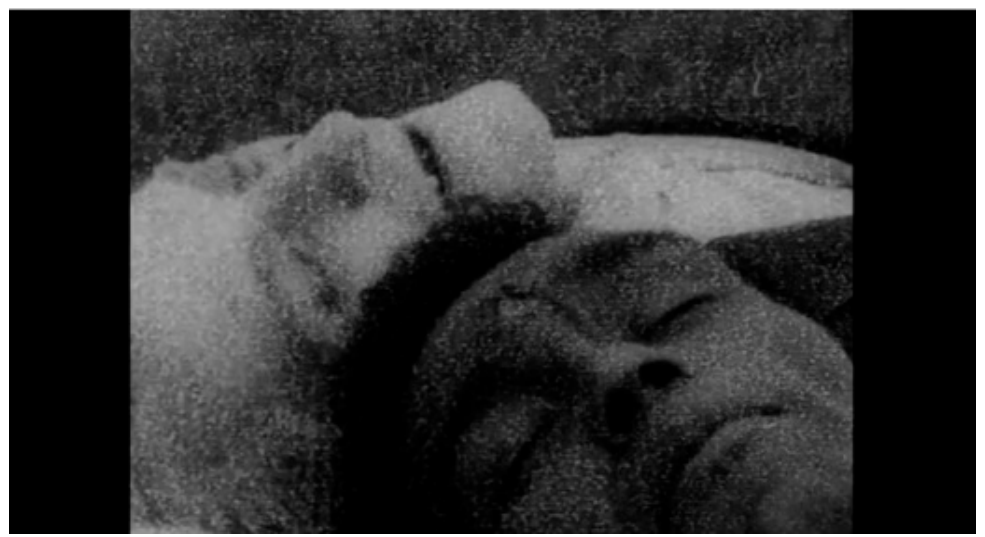

Figure 3. From the final sequence of Night of the Living Dead, the camera focuses on the faces of Ben and the film's first zombie, emphasizing similitude.

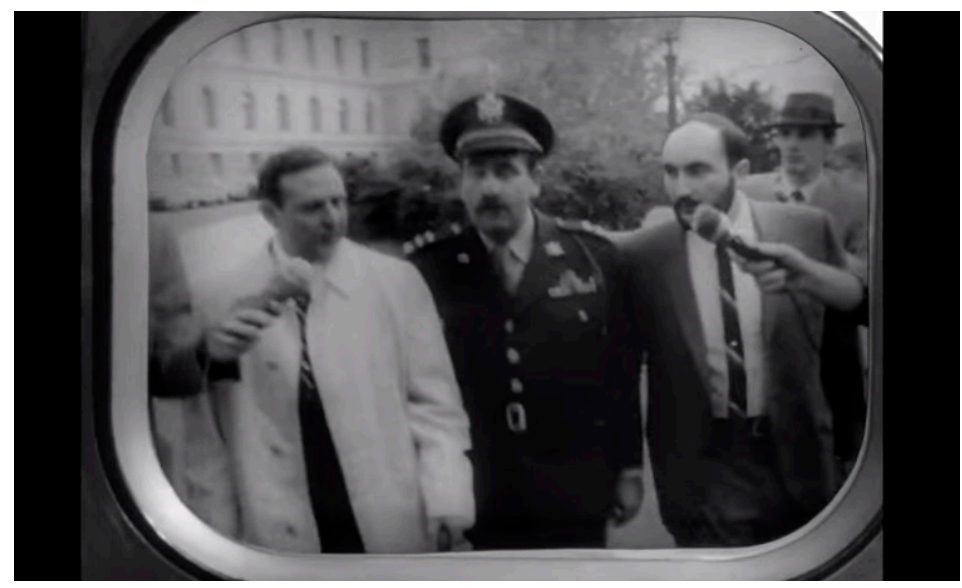

Figure 4. The TV frames our view, putting us in the room with the survivors. The framing of the image also implies the collusion of medicine, military, government, and media.

While Night of the Living Dead forces one to interrogate how society imagines alterity and justifies self-defensive violence, much of the zombie cinema following it revels in that self-defensive violence. Both the comic and television versions of The Walking Dead are exemplary in this regard: a character or characters question the supposed inhumanity of the zombies, only to have their ethical questions dismissed as dangerous luxuries. In this stock formulation, one character talks about how inhuman and monstrous the zombies are, emphasizing that they are no longer loved ones. Meanwhile, another character argues for sparing them violence on account of a possibly unforeseen latent humanity. Ultimately, the zombies prove too dangerous to even ethically consider, and prophylactic, self-defensive violence is meted out. If this scenario sounds too hypothetical, it plays out verbatim in issue 11 of 
the comic version of The Walking Dead and structures the primary conflict between Rick's group and Hershel's group in season 2 of the AMC adaptation [63,64].

If, as critics and fans of zombie cinema both attest, Night of the Living Dead is the primary structural influence on contemporary iterations of the genre, then the decreasing visibility of white supremacist patriarchal tension in contemporary narratives that was so overtly dramatized in Night of the Living Dead speaks to contemporary critiques of colorblindness in postracial formulations. The zombie isn't an empty signifier and never has been, but its relation to a socially and politically meaningful signified has been eroded through symptomatic reproductions of the genre form. Consequently, it is easy to understand why white folks are so into zombie fiction: it allows them to imagine a scenario in which the violent annihilation of any threat to their power or privilege is refigured as self-defense, and yet de-politicized because the very individuals assailing that power and privilege are revealed to be inhuman subject-objects. And yet, this discursive formulation and the hallmark structures of zombie narratives analyzed thus far are also directly visible in the narration of contemporary killings of black Americans.

\section{Vulnerable Lives, Anxious Subjects: Vulnerability, Self-Defense, and Structural Racism}

Due to the visibility produced through social media and protests by \#BlackLivesMatter, \#SayHerName, \#IfIDieInPoliceCustody, among others, the magnitude of racist violence (and its systemic nature and shocking repetition) has come into clearer focus [65]. As a result, the parallels between structures of violence in zombie narratives and the discursive structures surrounding contemporary killings of people of color have become increasingly visible, as well. The media and legal portrayal of black victims of racial violence belies a series of structural tendencies that uncannily parallel those identified above in the history of zombie narratives in the U.S. Namely: the individual is pathologized and dehumanized; the killer or killers categorize their response as self-defense justified by the pathological inhumanity they were faced with in the victim; the body of the victim is further reduced through media circulation to mere flesh to be biomedically analyzed as evidence. The coverage of the deaths of women of color is further complicated by their profusion of ellipses, symptomatically indicating a failure in the assemblages that justify violence. This essay cannot do each of these deaths the justice they deserve in this space, and I focus on one incident reluctantly, acknowledging the concern that this may further reify the victim. The last section of this essay looks briefly at the self-defensive narrative and autopsy information from one of the most visible of these cases, which is also the most paradigmatic in structure: Darren Wilson's shooting of Michael Brown. Before beginning an analysis of the autopsy information and defense, it is crucial to emphasize the localized, historical context that informs the case-an issue where a community was predominantly policed by those of a different race and socioeconomic status—and to emphasize that Michael Brown was an individual, with hopes and dreams and a personal life and personality; neither his life nor his death were archetypal, only the way in which his killer and the media narrated and made sense of this situation is common and generalizable. An examination of the rhetorical justification for violence toward Michael Brown demonstrates that the very vulnerability of the lives of people of color, their susceptibility to systemic violence, is also deployed as the justification for that violence: they are seen as threatening violence simply because they are so threatened by violence.

Pivotal to Darren Wilson's legal defense-and the media narration of the aftermath of Brown's death-was his narrative of self-defense, as was the case for George Zimmerman before him. The language used by Wilson eerily echoes the dehumanizing rhetorics used to justify violence in zombie narratives, and it seems to be functioning with much the same purpose, validating his legal claim to self-defense. It is important to remember that Darren Wilson's testimony to the Grand Jury was something for which he had time and legal help to prepare; his narration of events is certainly not randomly structured. It is particularly disturbing, then, that a police officer's validation of his use of deadly force as self-defense is parallel in structure to the narration of violence in zombie fictions. The following two paragraphs focus entirely on Wilson's defense of his use of force, portraying Brown 
as inhuman and monstrous; for that reason, the author would like to take a moment to emphasize Brown's humanity. Before he was a national headline, Brown was also a boy of 18 and a recent high school graduate soon to begin trade school [66]. In another world, Michael Brown could be a local success story, instead of a national tragedy. In Wilson's narration of events, framed to justify his use of deadly force, Brown is a suspect, a criminal, a demon, a monster, but never a human.

In Wilson's testimony, he dehumanizes and pathologizes Michael Brown, emphasizing Brown's monstrous rage and power as justification for self-defensive violence [67]. From his first mention of Brown, Wilson foreshadows his monstrous alterity, noting how, as he pulled up to Dorian Johnson and Michael Brown, "either the first one was really small, or the second one was really big" ([67], p. 207). The next thing that Wilson says he noticed were Brown's socks with "marijuana leaves" in pattern on them. Wilson claims that he pulled up in front of Brown and Johnson and asked each of them why they weren't walking on the sidewalk, to which Johnson allegedly responded "We are almost to our destination," and Brown stated "Fuck what you have to say" ([67], p. 208). This, he claims, is what drew his full attention to Brown, when he noticed the cigarillos in his hand, and when he realized that Brown and Johnson matched the description for a recent dispatch call about a cigarillo theft at a local convenience store. At this point, Wilson has emphasized Brown's notable stature, his uncooperative and angry demeanor, associated him via his clothing with illegal drugs, and finally noted that he believes Brown is a criminal. In other words, it is only after establishing his alterity, hostility, and potential criminality that Wilson goes on to narrate his conflict with Brown, reinforcing his monstrous alterity through his unprovoked violence and superhuman strength and stature.

After a scuffle over the opening of Wilson's car door, he describes Brown from his perspective: "At that time is when I saw him coming into my vehicle. His head was higher than the top of my car. And I see him ducking and as he is ducking, his hands are up and he is coming in my vehicle" ([67], p. 210). Here, Wilson emphasizes Brown's height and describes him as menacing, looming over him intending to do harm. He goes on to describe how at this point, he turned away and raised his arms in defense and Brown began to punch at his face through the open car window. Shortly after, Wilson describes how he, a 6'4" "210ish" pound man, "felt like a five-year-old holding onto Hulk Hogan" as he grappled with Brown ([67], p. 213). Wilson then sets up his decision to use his firearm, justifying that he "wasn't willing to sacrifice his left hand" which was blocking his face from the blows that Brown was throwing, so he couldn't reach for his mace or his asp (baton), emphasizing once again he "wasn't willing to let go of the one defense I had against being hit," so after some careful deliberation he drew his gun ([67], pp. 213-14). He continues to describe Brown as violent and aggressive, very deliberately cataloging his actions in self-defense, noting that he had already taken two punches to the face and fearing that "the third one could be fatal if he hit me right" ([67], p. 216). After a struggle over his gun, Wilson shoots Brown through the door-panel of his car, and he describes how Brown, now wounded, "had the most intense aggressive face" and "it looks like a demon, that's how angry he looked" ([67], p. 225). Wilson says Brown came at him again and, out of fear of what "looks like a demon," he shot Brown again. Note the decreasing humanity of Brown in this narrative, which culminates after Brown turns to run, wounded, and Wilson pursues. A few cars down, Brown turns around to face him, and Wilson describes how "he made like a grunting, like aggravated sound" and started charging toward Wilson while reaching under his shirt...and Wilson fired repeatedly ([67], p. 227).

Note how the reported monstrosity of Brown escalates throughout the Wilson's narrative, at first he is big, then he is looming and menacing, then demonic, and finally simply a grunting and aggravated monster. The final charge, where Brown is reduced to making "a grunting, like aggravated sound" echoes the framing of countless attacks in zombie fictions-where the zombie turns, grunts its inhuman grunt, and charges with death in its eyes (take, for example, the scene in Danny Boyle's 28 Days Later, where the infected soldier Mailer turns to attack his former comrades after being freed). Only, despite Wilson's narration of events, Brown wasn't a zombie, or a demon, or a monster. He was a boy of 18. In Wilson's account, the humanity of Brown diminishes increasingly as the narrator draws closer to using deadly force. It is, on one hand, a rhetorical strategy to emphasize his own action in 
self-defense-and one must remember that this is a rhetorical strategy to gain audience sympathy in a legal setting — but, it is also deploying the same structure as zombie narratives, justifying violence in a similar manner, reducing Brown to a beastly, animalistic, eventually monstrous state. Furthermore, Wilson's emphasis on Brown's face and the inhumanity he sees there emphasizes the impossibility of an ethical response; he looks into the boy's face and sees only a demon.

The media portrayal of these events complicates the situation, while unsettlingly deepening the relation to zombie narratives. Media coverage becomes preoccupied with forensics and scientific corroboration, as if corroborating details-who was where, when, what violence was done where, etc.-could somehow corroborate the veracity of one's entire narrative. The media obsession with the autopsy of Michael Brown emphasizes this point. Simply entering "Michael Brown autopsy" in a search engine gives one a sense of its fetishization (Figure 5):

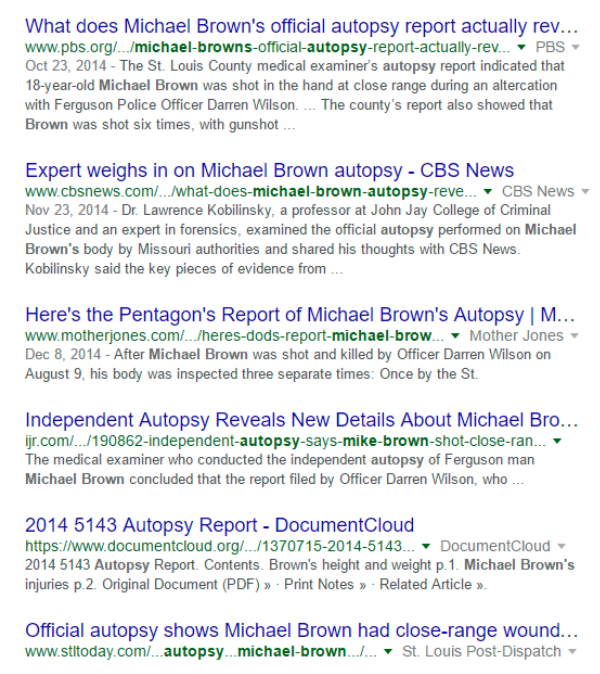

Figure 5. A screencap of results for the search terms "Michael Brown autopsy" already begins to reveal how the expert analysis emphasized in media coverage further reduced Michael Brown to mere flesh.

Media coverage of the case revolved around the protean accounts of events-including the purported theft that Wilson mentions in his testimony-and the autopsy became fetishized as a text that could be read against these accounts of events, as if through reading the severity and placement of wounds one could divine whether Michael Brown was a monstrous youth out to kill a cop, or a scared teenager trying not to get shot. In the process, the emphasis on expert analysis of Michael Brown's autopsied corpse further reified him, marking him as flesh that could not speak or stand for itself, but data that must be read. This, too, is paralleled in zombie fictions, where the scientific frame recasts ontological horror as dysgenic or pathological deficiency, and where the (un)dead cannot speak for themselves, but the scientist (or in early cases ethnographer) must speak for them.

There is, then, a disturbing amount of similitude between the way that we imagine the inhumanity, pathology, and alterity of zombies, the way violence is justified in zombie narratives, and the way that racialized violence in the U.S. is narrated and reported. This is true of gendered, racialized violence as well, as emphasized in the less visible nature and the profusion of ellipses in cases like of Sandra Bland, who mysteriously died in police custody after being violently arrested during a routine traffic stop. The narrative structures we have observed justifying racist violence seem to break down when faced with feminine subjects: we are left with ellipses and narratives untold, just as in Seabrook's and Hurston's accounts. Indeed, as the mother of Sandra Bland, Geneva Reed-Veal, has recently emphasized, we cannot narrate the story of Bland's death, nor that of five other women who died in police custody in the same year and whose deaths, unlike Bland's, were not even considered by national media [68]. This essay is intended to emphasize how vulnerable life is in the political contemporary, how crucial race is in making one vulnerable, and how that vulnerability functions: that life which is most threatened 
and exploited is simultaneously seen as most threatening. This reinforces how the burden of proof for self-defense-proving not that one's life was in mortal danger, but that one thought it was so-is shockingly inadequate: every police officer in a beleaguered community, every affluent person in a poor community, every colonizer among the colonized, and so on and so forth, can claim that they feared for their life. This justification of fear is both naturalized and normalized through the ubiquity of the zombie, whose contemporary narratives serve largely as a narrative wish fulfillment, validating anxieties of insecurity and justifying extreme violence. Recognizing this relationship, between the production of vulnerability and the reproduction of violence, is only a first step. The real work comes in promoting and producing new ways of imagining and approaching alterity, ways that eschew the objectification of a clinical gaze and the discourse of monstrous and pathological difference; ways that approach vulnerability without resorting to violence. This work already exists-Octavia Butler's science fiction does this and, at their best, the zombie fictions of Max Brooks and Bennett Simms do, too. In Citizen, Claudia Rankine writes, "because white men can't/police their imagination/black men are dying" [69], perhaps recalibrating the ways we imagine monstrosity, alterity, and violence in popular cultural texts, like zombie narratives, will help facilitate a shift in the way imaginations are policed, and violence justified. Zombie fictions need to recognize race and racial history, and show us not how the exceptional man survives, but how when some life is made vulnerable, all life is put in danger.

Acknowledgments: Thanks to the editor of this special issue, Myra Mendible, whose enthusiasm and encouragement early in the process gave me the courage to develop this paper. This essay revisits texts and themes I first visited years ago in my first publication, so many thanks to Dawn Keetley, who edited the collection that spurred the initial idea and provided crucial feedback on that essay. This article would not have been possible without the dialog provided by my panel-mates and colleagues at the 2015 meeting of the American Studies Association, and special thanks Emily Raymundo for bringing me aboard that panel. Thanks to the tireless work of colleagues like Anne Cong-Huyen and Amanda Phillips, who have continued to challenge me to ground my theoretical pursuits in practical matters and to face my own privilege in substantive and meaningful ways. And thanks to all those who offered sources and advice when I solicited them from the Facebook hive-mind: especially David Kim, Amanda Phillips (again), and Kim Knight. And a second thanks to Anne Cong-Huyen, for her labor in reading an early draft and providing feedback and reassurance. Many thanks to the peer-reviewers who took the time to thoughtfully engage with this piece, your feedback was invaluable in deepening the conceptual framework of the essay and better elaborating its stakes. Finally, thanks to the editorial staff at Humanities for all their timely help and enduring patience.

Conflicts of Interest: The author declares no conflict of interest, aside from his own privileged subject position, which is still worth noting.

\section{References and Notes}

1. Michelle Alexander. The New Jim Crow: Mass Incarceration in the Age of Colorblindness, rev. ed. New York: The New Press, 2012.

2. Khalil Gibran Muhammad. The Condemnation of Blackness: Race, Crime, and the Making of Modern Urban America. Cambridge: Harvard University Press, 2010.

3. Sociologists for Justice. "Ferguson syllabi." Available online: https://sociologistsforjustice.org/fergusonsyllabus/ (accessed on 4 November 2016).

4. Mic.com. "A Ferguson Syllabus: Reading a Moment." Available online: http://mic.com/articles/123509/ best-articles-on-ferguson-unrest-and-michael-brown-shooting\#.XxIVqqD29 (accessed on 4 November 2016).

5. Isabel Wilkerson. "Mike Brown's shooting and Jim Crow lynching have too much in common. It's time for America to own up." The Guardian, 25 August 2014. Available online: http://www.theguardian. com/commentisfree/2014/aug/25/mike-brown-shooting-jim-crow-lynchings-in-common (accessed on 4 November 2016).

6. Martell Teasley, and David Ikard. "Barack Obama and the Politics of Race: The Myth of Postracism in America." Journal of Black Studies 40 (2010): 411-25. [CrossRef]

7. Michael Omi, and Howard Winant. "Colorblindness, Neoliberalism, and Obama." In Racial Formation in the United States, 3rd ed. New York: Routledge, 2015, pp. 211-44. 
8. Robert A. Williams, Jr. “Documents of Barbarism The Contemporary Legacy of European Racism and Colonialism in the Narrative Traditions of Federal Indian Law." In Critical Race Theory the Cutting Edge, 3rd ed. Edited by Richard Delgado and Jean Stefancic. Philadelphia: Temple University Press, 2013, pp. 125-35.

9. Samuel Walker, Cassia Spohn, and Miriam DeLone. The Color of Justice: Race, Ethnicity, and Crime in America, 5th ed. Boston: Cengage Learning, 2011, p. 53.

10. Aileen Moreton-Robinson. "Writing Off Treaties: Possession in the Critical U.S. Whiteness Literature." In The White Possessive: Property, Power, and Indigenous Sovereignty. Minneapolis: Minnesota University Press, 2015, pp. 47-61.

11. White Zombie. Directed by Victor Halperin. United Artists, 1932. The first feature-length zombie film, White Zombie, drew directly from-And was reportedly directly inspired by-W. B. Seabrook's The Magic Island.

12. William B. Seabrook. The Magic Island. New York: Harcourt, Brace, and Co., 1929.

13. Andrew Norris. "Giorgio Agamben and the Politics of the Living Dead." Diacritics 30 (2000): 38-58. [CrossRef]

14. Willem Schinkel. "'Illegal Aliens' and the State, or: Bare Bodies vs. the Zombie." International Sociology 24 (2009): 779-806. [CrossRef]

15. Nikos Papastergiadis. "Wog Zombie: The De- and Re-Humanisation of Migrants, from Mad-Dogs to Cyborgs." Cultural Studies Review 15 (2009): 147-78. Papastergiadis directly addresses the relation of the zombie to the figure of the migrant and biopolitical theory, but he does so briefly, as one example among a broader set of fictional refigurations of migrants. [CrossRef]

16. Jon Stratton has published a couple works that productively think through the relation of real world biopolitics and contemporary zombie cinema. See Jon Stratton. "Zombie trouble: Zombie texts, bare life, and displaced people." European Journal of Cultural Studies 14 (2011): 265-81.

17. Jon Stratton. "The Trouble with Zombies: Bare Life, Musselmänner, and Displaced People." Somatechnics 1 (2011): 188-201. [CrossRef]

18. Tyson E. Lewis. “Ztopia: Lessons in Post-Vital Politics in George Romero's Zombie Films." In Generation Zombie: Essays on the Living Dead in Modern Culture. Edited by Stephanie Boluk and Wylie Lenz. Jefferson: McFarland and Company, 2011, pp. 90-100. Lewis cannily relates Agamben's biopolitical theory to George Romero's zombie films, analyzing how the films reimagine and comment upon the political order.

19. Christopher Moreman, and Cory Rushton, eds. Race, Oppression, and the Zombie: Essays on the Cross-Cultural Appropriation of the Caribbean Tradition. Jefferson: McFarland and Company, 2011. This collection of essays is precisely attuned to the historical relation of the zombie to four different themes: Race, slavery, and history; Capital; cultural appropriations of the figure; and philosophical and religious affects. The first section of the book does great work with race and history and the book, writ large, is valuable; however, it does not connect the concerns of biopolitical theory and contemporary racial violence to the figure of the zombie.

20. Gerry Canavan. "'We are the Walking Dead': Race, Time, and Survival in the Zombie Narrative." Extrapolation 51 (2010): 431-53. [CrossRef]

21. Paul Gilroy. "'My Britain is fuck all' zombie multiculturalism and the race politics of citizenship." Identities: Global Studies in Culture and Power 19 (2012): 380-97. [CrossRef]

22. Travis Linnemann, Tyler Wall, and Edward Green. "The walking dead and killing state: Zombification and the normalization of police violence." Theoretical Criminology 2014. [CrossRef]

23. The above three sources, in very different ways, unpack the relation of race, violence, and biopolitics to the cultural figure of the zombie and very much already do the work for which this essay advocates.

24. Judith Butler. Precarious Life: The Powers of Mourning and Violence. New York: Verso, 2004.

25. Achille Mbembe. “Necropolitics." Public Culture 15 (2003): 11-40. [CrossRef]

26. Mel Y. Chen. Animacies: Biopolitics, Racial Mattering, and Queer Affect. Durham: Duke University Press, 2012.

27. Giorgio Agamben. Homo Sacer: Sovereign Power and Bare Life. Translated by Daniel Heller-Roazen. Stanford: Stanford University Press, 1998.

28. Alexander G. Weheliye. Habeas Viscus: Racializing Assemblages, Biopolitics, and Black Feminist Theories of the Human. Durham: Duke University Press, 2014.

29. Nancy Kass. “Ebola, Ethics, and Public Health: What Next?” Annals of Internal Medicine 161 (2014): 744-45. [CrossRef] [PubMed] 
30. William Booth. "The U.N. Says 7 in 10 Palestinians Killed in Gaza were Civilians. Israel Disagrees." The Washington Post, 29 August 2014. Available online: https://www.washingtonpost.com/world/ middle_east/the-un-says-7-in-10-palestinians-killed-in-gaza-were-civilians-israel-disagrees/2014/08/ 29/44edc598-2faa-11e4-9b98-848790384093_story.html (accessed on 26 October 2014).

31. Glenn Greenwald. "'Militants': Media Propaganda." Salon, 2011. Available online: http:/ /www.salon.com/ 2012/05/29/militants_media_propaganda/(accessed on 15 April 2016).

32. Rob Nixon. Slow Violence and the Environmentalism of the Poor. Cambridge: Harvard University Press, 2013.

33. Julia Craven, and Tyler Tynes. "The Racist Roots of Flint's Water Crisis." The Huffington Post, 3 February 2016. Available online: http://www.huffingtonpost.com/entry/racist-roots-of-flints-watercrisis_us_56b12953e4b04f9b57d7b118 (accessed on 15 April 2016).

34. EGP Staff Report. "DTSC Accused of 'Environmental Racism.'.” EGP News, 19 February 2015. Available online: http:/ /egpnews.com/2015/02/dtsc-accused-of-environmental-racism/ (accessed on 15 April 2016). During the investigation of contamination and damages, a series of "racially charged" emails within the DTSC also fueled arguments that the lack of regulation and slow reaction in Vernon and the surrounding areas reflected environmental racism.

35. Scott Lauria Morgensen. "The Biopolitics of Settler Colonialism: Right Here, Right Now." Settler Colonial Studies 1 (2011): 52-76. [CrossRef]

36. Sylvia Wynter. “'No Humans Involved': An Open Letter to my Colleagues.” Forum N.H.I.: Knowledge for the 21st Century 1 (1994): 42-73.

37. Sylvia Wynter. “On Disenchanting Discourse: 'Minority' Literary Criticism and Beyond." Cultural Critique 7 (1987): 207-44. [CrossRef]

38. Giorgio Agamben. State of Exception. Chicago: University of Chicago Press, 2008, p. 3.

39. "vulnerable, adj." Oxford English Dictionary. Available online: http://www.oxforddictionaries.com/ definition/english/vulnerable (accessed on 28 August 2016).

40. Foucault acknowledges the structural function of race and racism in biopolitics in Society Must Be Defended-And Weheliye's critique of the role of race in that text is excellent-And one can trace biopolitical discourse back before Foucault until at least 1911, where the term was consciously coined in the British modernist little magazine The New Age. In that magazine, G. W. Harris published an essay titled "Bio-Politics" which advocated for legislative policies that both governed biology and biologically governed. Particularly, he advocated for negative eugenic policies to reduce the female population in England and to experiment upon or euthanize the disabled population there. A smattering of socio-political theorizations then took on the mantle-Most notably Morley Roberts's Bio-Politics in 1938 and Thomas Landon Thorson's Biopolitics in 1970. Throughout these pre-Foucauldian theorizations of the biopolitical, the role of race, sexuality, and ability in structuring political and social fitness is paramount. When Foucault says that the history of biopolitics is tied to the history of race, racism, and race war, it is literally true.

41. Susan Sontag. "The Imagination of Disaster." Commentary 40 (1965): 42-48.

42. Vishanthie Sewpaul. "Inscribed in Our Blood: Challenging the Ideology of Sexism and Racism." Affilia: Journal of Women and Social Work 28 (2013): 116-25. [CrossRef]

43. John H. Craige. Black Bagdad: The Arabian Nights Adventures of a Marine Captain in Haiti. New York: Minton, Balch, and Company, 1933.

44. John H. Craige. Cannibal Cousins. New York: Minton, Balch, and Company, 1934.

45. Hans Schmidt. The United States Occupation of Haiti, 1915-1934. New Brunswick: Rutgers University Press, 1995. See this source for more on the political and corporate context for the U.S. occupation of Haiti.

46. Mary A. Renda. Taking Haiti Military Occupation and the Culture of U.S. Imperialism, 1915-1940. Chapel Hill: University of North Carolina Press, 2001, See Renda's history for a more critical account of U.S. paternalism and imperialism in the occupation of Haiti.

47. Roberto Strongman. "The Body of Vodou." In Literary Expressions of African Spirituality. Edited by Carol P. Marsh-Lockett and Elizabeth J. West. Lanham: Lexington Books, 2013.

48. Roberto Strongman. "Transcorporeality in Vodou." The Journal of Haitian Studies 14 (2008): 4-29.

49. Maya Deren. Divine Horsemen: The Living Gods of Haiti. Hoboken: Wiley, 1953, p. 58.

50. Leslie G. Desmangles. "The Maroon Republics and Religious Diversity in Colonial Haiti." Anthropos 85 (1990): 475-82. 
51. Susan Zieger. "The Case of William Seabrook: Documents, Haiti, and the Working Dead." Modernism/Modernity 19 (2012): 737-54. [CrossRef]

52. An exemplary text that reproduces these problematic perspectives is: Erwin Baur, Eugen Fischer, and Fritz Lenz's. Human Heredity (Menschliche Erblichkeitslehre in the original German). New York: The Macmillan Company, 1931. This was a popular example of the way that eugenics, biopolitics, and racial biology demonstrated differential definitions and valuations of human-ness and naturalized an legitimated them through scientific discourse. The first English edition was published in 1931, but it was based on the third edition in German (1927).

53. Zora Neale Hurston. Tell My Horse. New York: Harper Perennial/Modern Classics, 1990.

54. Wade Davis. The Serpent and the Rainbow. New York: Simon \& Schuster, 1985.

55. Wade Davis. Passage of Darkness. Chapel Hill: University of North Carolina Press, 1988.

56. Night of the Living Dead. Directed by George A. Romero. Madacy Entertainment, 1998. Originally released to theaters in 1968.

57. Matt Mogk. Everything You Ever Wanted to Know About Zombies. New York: Gallery Books, 2011.

58. Kevin Boon. "And the Dead Shall Rise." In Better Off Dead: The Evolution of the Zombie as Post-Human. Edited by Deborah Christie and Sarah Juliet Lauro. New York: Fordham University Press, 2011, pp. 5-8.

59. Dawn Keetley. "Introduction: 'We're All Infected.'." In "We're All Infected": Essays on AMC's The Walking Dead and the Fate of the Human. Jefferson: McFarland Publishing, 2014, pp. 3-25.

60. Deborah Christie. "A Dead New World: Richard Matheson and the Modern Zombie." In Better Off Dead: The Evolution of the Zombie as Post-Human. Edited by Deborah Christie and Sarah Juliet Lauro. New York: Fordham University Press, 2011, pp. 67-80.

61. Steven Pokornowski. "Burying the Living with the Dead: Security, Survival, and the Sanction of Violence." In "We're All Infected": The Walking Dead and the Fate of the Human. Edited by Dawn Keetley. Jefferson: McFarland and Company, 2014, pp. 41-55.

62. Although I do not have the time or space to address it here, I would like to suggest that these are two possible responses to vulnerable life: to isolate and protect one's own gains, or to come together and collaborate.

63. The Walking Dead. Created by Frank Darabont. AMC, 2010.

64. Robert Kirkman, Charlie Adlard, and Cliff Rathburn. The Walking Dead. Berkeley: Image Comics, 2004.

65. It is important to see how this violence is both widespread and unequally aimed at people of color. The Guardian noted, that 300 of the 1134 people killed by police in the U.S. were African American. A skeptic might argue that pales in comparison to the 577 white people killed by police in the same year, but when one realizes that African Americans account for only 2\% of the national population and are more than twice as likely to be killed by police than other groups, the inequity seems undeniable. See: Jon Swaine, Oliver Laughland, Jamiles Lartey, and Ciara McCarthy. "Young black men killed by US police at highest rate in year of 1134 deaths." The Guardian, 31 December 2015. Available online: http:/ /www.theguardian.com/ us-news/2015/dec/31/the-counted-police-killings-2015-young-black-men (accessed on 13 May 2016).

66. Wesley Lowery, and Todd C. Frankel. "Mike Brown notched a hard fought victory just days before he was shot: A diploma." The Washington Post, 2014. Available online: https: / /www.washingtonpost.com/politics/mike-brown-notched-a-hard-fought-victory-just-days-beforehe-was-shot-a-diploma/2014/08/12/574d65e6-2257-11e4-8593-da634b334390_story.html (accessed on 1 August 2016).

67. The court documents from Wilson's Grand Jury Trial have been released to the public. CNN has published and archived them for easy use. Wilson's testimony begins on page 195 of the document titled "Grand Jury Volume 5." Available online: https://www.documentcloud.org/documents/1370518-grand-jury-volume-5. html (accessed on 28 July 2016).

68. Candice Norwood. "Sandra Bland's mother wants you to know the other black women who died in police custody." Vox. Available online: www.vox.com/identitites/2016/5/4/11580588/sandra-bland-mother (accessed on 31 May 2016).

69. Claudia Rankine. Citizen. Minneapolis: Graywolf Press, 2014, p. 135. Rankine's short, poetic/theoretical/ critical book is staggering and crucial.

(C) 2016 by the author; licensee MDPI, Basel, Switzerland. This article is an open access article distributed under the terms and conditions of the Creative Commons Attribution (CC-BY) license (http://creativecommons.org/licenses/by/4.0/). 